\title{
Optimum Production and Maximum Profit
}

\section{Fanie Brink*}

Independent Agricultural Economist, University of Pretoria, South Africa

*Corresponding Author: Fanie Brink, Independent Agricultural Economist, University of Pretoria, South Africa.

Received: June 28, 2019; Published: July 04, 2019

DOI: 10.31080/ASAG.2019.03.0560

The principle of "optimum production and maximum profit" is very old and it is the most important principle in the agricultural industry as all the different disciplines are involved in the implementation of the principle. Specifically, because it determines the profitability of farming enterprises without which financial survival is not possible.

Increasing the combined profitability of all the business enterprises across the individual industries in the primary, secondary and tertiary sectors of the economy is the only way to create economic growth. The profit motive is the main driver of economic growth in a capitalist economic system based on the private ownership of all the factors of production, such as land and raw materials, capital, labour and management, while its prices, utilisation and mobility are basically determined by the market forces of supply and demand.

The fact of the matter is that food security can only be sustainable if food production is profitable.

The principle "optimum production and maximum profit" was defined and mathematically described in the 1950's by two postgraduate students of professor Earl, 0 Heady, head of the Department of Agricultural Economics at the Iowa State University in the USA The mathematical equation of the production function is known as the Cobb-Douglas production function, named after these two students. This principle clearly sets out the two factors (driving forces) that determine the profitability and sustainability of all the different enterprises in agriculture and therefore the contribution that the agricultural industry can make to economic growth.

\section{Input/output-price ratio}

The first and most important factor (driver of profitability) in agricultural production is the relationship between the changes in the prices paid by producers for their inputs against the changes in the prices they receive for their products, the so-called input/ output-price ratio.

Research has proven that the prices of inputs are rising at a faster rate than the prices of agricultural products and this phenomenon still has a huge impact on the rising production costs and profitability in agriculture. The main reason for this is the fact that the suppliers of agricultural inputs determine their prices based on their total production cost plus a profit margin, while the prices of agricultural products are determined purely by the market forces of supply and demand. In addition, as the climate is very volatile, producer prices cannot keep up with the input price increases.

The influence of the international prices of agricultural inputs, the exchange rate and the high import costs also have a huge impact on local input prices. Mainly due to the dumping of production surpluses and subsidised products in the international market and the unwillingness of the government to introduce appropriate import tariffs that can protect the agricultural industry against this unfair competition.

Another important reason for this problem is the fact that the government regulates some of the key inputs, including fuel prices, electricity tariffs and minimum wages, through legislation that are experiencing sharp increases on a regular basis.

Agricultural producers are price-makers and not price-makers and the fact that prices of agricultural products are determined by supply and demand, means that agricultural producers do not also have the luxury of passing their production cost increases on to the end-consumers, such as the processors, manufacturers and food traders, who also base their prices to consumers on their total production cost plus a profit margin. Therefore, consumer prices are also rising faster than the producer prices of agricultural products, which could negatively impact on the demand for food. 
The management and hedging of the production and price risks of agricultural products such as grains, oilseeds, wool and beef which trade on the South African Futures Exchange (SAFEX) also play a very important role in the determination of the input/output-price ratio and the profitability of production.

Another important reason that has a very adverse effect on the profitability of agriculture is the production of surpluses. The inherent characteristics of the demand for food compared to the demand for durable goods cause agricultural products to struggle with a price-inelastic demand curve. This means that a reduction in product prices, for example, by 20 percent or more due to climatic conditions that can cause surplus production, does not result in a corresponding increase in the demand for agricultural products.

The changes in the price ratio are very important, for example, the general norm used in the feedlot industry that the price of beef per kilogram must be at least 15 times higher than the price of maize per kilogram in order to reach a break-even point.

An investigation into the production of bioethanol from maize in 2005 showed that the price of bioethanol in kilo-liters should be at least 2,6 times higher the price of maize to break-even. Any change in the price ratio will directly affect the profitability of an ethanol plant.

\section{Efficiency of production}

The "efficiency of production" is the second most important factor (driver of profitability) which together with the "input/output price ratio," determines the "optimum production and maximum profit" level of any agricultural enterprise. The fact that all agricultural production processes are biological processes makes it subjected to the Law of Diminishing Returns.

This Law clearly states that when production inputs are applied to a particular production unit, for example a hectare planted with any cereal, oilseed or vegetable crops, a dairy cow or a weaner fed and rounded off in a feedlot, there are three specific stages of production emerging as more inputs are applied and the production increases further, as shown in the accompanying table.

For example, in the case of a cereal such as maize, the plant reacts very well after the application of the first, for example, 50 kilograms of fertilizer which increases the yield rapidly. The further applications of additional units of 50 kilogram each, make an increasing contribution to the total production in this first phase, as shown in the table for illustration purposes, and is known as the "increasing returns" phase.

\begin{tabular}{|c|c|c|c|}
\hline \multicolumn{3}{|c|}{ Law of Diminishing Returns } & \\
\hline $\begin{array}{c}\text { Fertiliser } \\
\text { application }\end{array}$ & $\begin{array}{c}\text { Changes in } \\
\text { yield }\end{array}$ & $\begin{array}{l}\text { Total } \\
\text { yield }\end{array}$ & \\
\hline $\mathrm{Kg} / \mathrm{ha}$ & Ton/ha & Ton/ha & \\
\hline 50 & 0,2 & 0,2 & \\
\hline 50 & 0,4 & 0,6 & \\
\hline 50 & 0,7 & 1,3 & Increasing returns \\
\hline 50 & 1,1 & 2,4 & \\
\hline 50 & 1,7 & 4,1 & \\
\hline 50 & 2,5 & 6,6 & \\
\hline 50 & 2,1 & 8,7 & \\
\hline 50 & 1,6 & 10,3 & \\
\hline 50 & 1,0 & 11,3 & Diminishing returns \\
\hline 50 & 0,3 & 11,6 & \\
\hline 50 & 0,1 & 11,7 & \\
\hline 50 & $-0,5$ & 11,2 & \\
\hline 50 & $-0,7$ & 10,5 & Negative returns \\
\hline 50 & $-0,9$ & 9,6 & \\
\hline \multicolumn{3}{|c|}{ (For illustration) } & \\
\hline
\end{tabular}

Table

In this phase, the marginal (additional) income, which is the price of maize multiplied by the increase in the additional production, is in each case greater than the marginal (additional) cost, which is the price of the fertiliser multiplied by the amount of the additional fertiliser applied, thereby increasing the profitability of production.

By applying more fertilizer, the "diminishing returns" phase is then entered when the additional production increases at a declining rate that make a smaller contribution to the total production each time, although it is increasing further. In this phase, the marginal income is starting to rise more slowly, although it is still larger than the marginal costs and, therefore, continues to increase production.

The most important point on the production curve is then reached, as indicated in the accompanying graph, where the marginal income and the marginal costs are equal, which then determines the "optimum production and maximum profit" level of production.

If more and more fertiliser were to be applied to this point, which would still increase the total production, the marginal costs would be greater than the marginal income and the profitability of production would consequently begin to decrease. Therefore, it can 
be concluded that the maximum production is not also the maximum profitable level of production.

The "optimum production and maximum profit" level of production, according to the mathematical equation, is then that point on the production curve where the change in the amount of maize produced in relation to the amount of fertiliser applied is equal to the change in the reverse price ratio between maize and fertiliser prices, as shown in the accompanying graph, which is in fact nothing other than the point where the change in marginal revenue is equal to the change in marginal costs, as mentioned above.

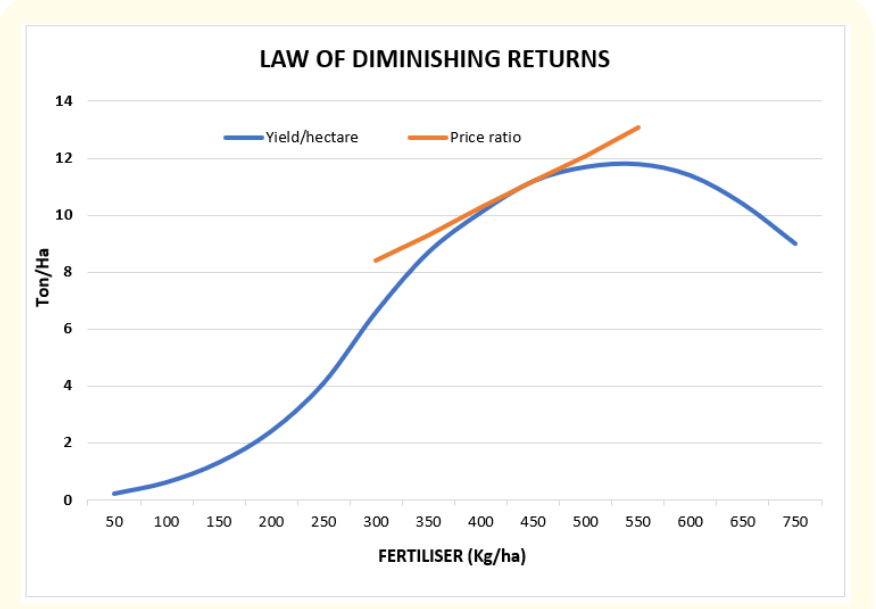

Figure

However, it is important to note that the "optimum production and maximum profit" level of production can also shift on the production curve due to changes in maize and fertiliser prices.

The third phase of production will simply be the phase in which more fertiliser is applied, but which will adversely affect the plant's growth and yield and will result in a decrease in the additional and total production, as well as profitability.

The efficiency of production can and must be improved to continue to make an important and greater contribution to profitability by applying the best and latest technological developments, specifically the technology resulting from the so-called fourth industrial revolution such as robotics, artificial intelligence, nanotechnology, quantum computing and autonomous vehicles into account. It must enable producers to produce more with the same quantity of inputs or to produce the same quantity of outputs with fever inputs.

For example, if 7 kilograms of a balanced animal feed ration is needed to produce 1 kilogram of beef in a feedlot, these requirements can be reduced to 6 kilograms by improving the feed ration, as well as the feed conversion potential and disease resistance of the cattle fed in a feedlot by further research and technological developments.

In the United States the bio-ethanol (ethylene-alcohol) plants which produce and blend bio-ethanol with a fossil fuel such as petrol have succeeded to increase the bio-ethanol yield from 180 to 220 liters per ton of maize by the development of new enzymes which is used in the fermentation process.

New enzymes have also been developed that significantly reduced the temperatures in the cooking process of the maize, which had a positive effect on the net energy value of the plants. Further technological development also succeeded in developing maize cultivars with a higher fermentable starch content and making it available to producers which had a dig financial advantage for the plants and a better maize price for the producers.

A good example of how the efficiency of production has increased over time can be found in maize production in South Africa. The average yield of maize has increased from an average of 2 tons to 4 tons per hectare over the past 40 years. This excellent increase in the efficiency with which the maize crop was produced over time can be directly attributed to several reasons.

Firstly, the continued research and major technological developments over many years played a very important role in increasing the efficiency of maize production. Especially in terms of seed breeding and genetic modification techniques, the development of new active ingredients in herbicides and pesticides, new fertilizer products and better application methods, as well as new advanced mechanical and electronical technology developments in agricultural mechanization such as, for example, precision farming.

Secondly, the application of fertilizer was scaled down since the 1980 's while much fewer tractors and machinery have been purchased as well. Maize producers have also made a major adjustment since 1988/89 to increase the efficiency of production by extracting almost $25 \%$ of the low potential soils from production and converting it to planted pastures. Producers also applied an overlay planting system for soil moisture conservation to reduce yield risks in lower rainfall production areas.

All these factors worked together to increase the efficiency of maize production as a result of the application of less and more technologically advanced inputs which delivered higher yields per hectare and resulted in an increased production and profitability.

\section{Volume 3 Issue 8 August 2019 (c) All rights are reserved by Fanie Brink.}

